\title{
PERANAN ORGANISASI SISWA INTRA SEKOLAH (OSIS) DALAM MEMBENTUK KARAKTER SISWA DI SMK NEGERI 2 SALATIGA
}

\author{
Indra Anggrio Toni \\ Program Studi S1 Pendidikan Pancasila dan Kewarganegaraan \\ FKIP- Universitas Kristen Satya Wacana \\ 172014008@student.uksw.edu \\ Nani Mediatati \\ Program Studi S1 Pendidikan Pancasila dan Kewarganegaraan \\ FKIP - Universitas Kristen Satya Wacana \\ nani.mediatati@uksw.edu
}

\begin{abstract}
One of the negative impact of globalization era is the decreasing of the character of senior high school' students. This case can be seen from many kinds of offenses of the students such as bring pornographic readings, skipping classes, smoking, and brawls. Therefore, one of the effort of the school to overcome the problems is through student council. The purpose of this research is to describe the role of the student council in forming the students' characters in Vocational High School 2 in Salatiga from (1) student council's work programs that have been arranged and done, (2) the students character formation through student council's activities, (3) the successful implementation of student council activities in shaping the students' character. Descriptive research is used in this study and the participants are the chairman and members of the student council, and student council adviser. The data collection used interview, observation, and documentation. The results of the research showed: (1) there were 4 activities or programs of student council such as class meetings, the representative meeting, the introduction of the school environment, and basic leadership training, (2) Four activities or programs formed the students' character such as discipline, confidence, responsibility, mutual respect, democracy, caring, critical, and leadership, (3) the programs are done successfully to change the students' character who were less disciplined to be more disciplined, responsible to do homework, caring to friends, critical and confident in giving opinions in front of the class or public, cooperated well and respected to teachers.
\end{abstract}

Keywords: Role, Student Council, Character Education

\section{PENDAHULUAN}

Salah satu dampak negatif era globalisasi adalah merosotnya karakter siswa sekolah menengah atas, hal ini terlihat dari berbagai pelanggaran yang sering dilakukan oleh siswa misalnya aksi corat coret, membawa alat main atau bacaan atau gambar porno, merokok atau terlibat narkoba, dan perkelahian antar sekolah atau tawuran (Nursisto, $2002: 2)$.

Gejala kemerosotan moral dan karakter diatas, akan dapat membahayakan keberlanjutan kehidupan bangsa terutama pada perkembangan siswa sebagai penerus bangsa, oleh karena itu dibutuhkan langkah preventif salah satunya melalui pendidikan. Pendidikan menjadi sektor yang sangat penting untuk diperhatikan sebagai bagian dari 
kegiatan mencerdaskan anak-anak bangsa dan mampu membentuk karakter anak-anak bangsa yang bermoral dan menerapkan nilai-nilai moral yang sesuai dengan budaya bangsa Indonesia.

Pendidikan karakter saat ini sangat penting dilakukan bagi siswa di tengah derasnya gempuran pengaruh negatif dari media massa dan lingkungan. Menurut Suyatri, Darmiati dan Bintoro (2013: 47), pendidikan karakter bertujuan untuk membentuk bangsa yang tangguh, kompetitif, berakhlak mulia, bermoral, bertoleran, bergotong royong, berjiwa patriotik, berkembang dinamis, berorientasi pada ilmu pengetahuan dan teknologi yang semuanya dijiwai oleh iman dan taqwa kepada Tuhan Yang Maha Esa berdasarkan pancasila. Oleh karena itu lembaga pendidikan formal sebagai wadah resmi pembinaan generasi muda diharapkan dapat meningkatkan peranannya dalam membentuk kepribadian peserta didik melalui peningkatan intensitas dan kualitas pendidikan yang memuat tentang karakter. Salah satu cara yang dapat diterapkan oleh sekolah dalam rangka mengatasi permasalahan karakter peserta didik adalah dengan melaksanakan kegiatan ekstrakurikuler seperti Pramuka, OSIS, Paskibra, dan Palang Merah Remaja. Salah satu kegiatan ekstrakurikuler yang dilakukan hampir di setiap sekolah di Indonesia yaitu OSIS. Menurut Gunawan Heri (2012 : 263) Organisasi siswa intra sekolah (OSIS) berfungsi sebagai wadah kegiatan siswa di sekolah sebagai upaya preventif dalam menyelesaikan masalah perilaku menyimpang dari siswa dan juga sebagai sarana perwujudan dari pemahaman siswa tentang sikap demokrasi di sekolah. Salah satu jalur pembinaan karakter siswa ialah melalui OSIS yang merupakan salah satu organisasi siswa yang diakui keberadaannya dalam menampung aspirasi siswa dan wadah penyaluran kegiatan sesuai dengan bakat dan minat siswa di luar kurikulum yang sudah diatur.

SMK Negeri 2 Salatiga merupakan salah satu sekolah menengah kejuruan di Kota Salatiga yang juga mengalami permasalahan menurunnya karakter siswa dalam bentuk pelanggaran terhadap tata tertib sekolah. Berdasarkan wawancara terhadap bapak Sujoko wakil kepala sekolah bagian kesiswaan bentuk - bentuk pelanggaran terhadap tata tertip sekolah tersebut antara lain; siswa hadir di sekolah lebih dari pukul 07.00 dan meninggalkan kelas tanpa izin/membolos; siswa tidak mengikuti upacara bendera; siswa tidak menggunakan pakaian seragam sesuai dengan ketentuan sekolah; siswa tidak menghargai dan menghormati guru dan teman (berbicara/bertingkah laku tidak sopan). Jumlah siswa SMK N 2 Salatiga yang melanggar tata tertip sekolah tersebut dari kelas X sampai XII pada tahun ajaran 2017/2018 dengan sanksi point 11-25 sebanyak 314 siswa dari keseluruhan siswa 1894 orang (data bagian kesiswaan SMK N 2 Salatiga). Melalui pelaksanaan kegiatan ekstrakurikuler OSIS diharapkan dapat mengatasi permasalahan menurunnya karakter siswa tersebut, karena semua siswa wajib menjadi anggota OSIS.

Berdasarkan latar belakang diatas, maka dilakukan penilitian tentang "Peranan organisasi siswa intra sekolah (OSIS) dalam membentuk karakter siswa di SMK Negeri 2 Salatiga". Penilitian ini bertujuan untuk mengetahui kegiatan/program yang disusun dan dilaksanakan oleh OSIS, karakter siswa yang dibentuk melalui kegiatan-kegiatan OSIS, dan keberhasilan pelaksanaan kegiatan-kegiatan OSIS dalam membentuk karakter siswa. 


\section{KAJIAN TEORI}

\section{Pendidikan Karakter}

Pendidikan adalah usaha sadar untuk menumbuh kembangkan potensi sumber daya manusia (SDM) melalui kegiatan pengajaran. Pendidikan mempunyai posisi yang strategis dalam rangka peningkatan kualitas sumber daya manusia,dan posisi yang strategis tersebut dapat tercapai bila pendidikan yang dilaksanakan mempunyai kualitas (Setiawan, O, 2018: 1), Karakater adalah kumpulan tata nilai yang menuju pada suatu sistem, yang melandasi pemikiran, sikap, dan perilaku yang ditampilkan. Karakter adalah bawaan, hati, jiwa, kepribadian, budi pekerti, perilaku, personalitas, sifat, tabiat, temperamen, dan watak. Karakter tidak diwariskan, tetapi sesuatu yang dibangun secara berkesinambungan hari demi hari melalui pikiran dan perbuatan, pikiran demi pikiran, tindakan demi tindakan (Zubaedi, 2012:8 ). Jadi pendidikan karakter dapat didefinisikan sebagai usaha sadar untuk menumbuhkan kualitas sumber daya manusia (SDM) melalui kegiatan pengajaran dalam melandasi pemikiran, sikap, dan kepribadian yang ditampilkan. Menurut Lickona dalam Samani dan Hariyanto ( 2011 : 44 ), pendidikan karakter didefinisikan sebagai upaya yang sungguh-sungguh untuk membantu seseorang memahami, peduli, dan bertindak dengan landasan inti nilai-nilai etis.

Adapun tujuan pendidikan karakter menurut Kusuma (2011:9) antara lain: meningkatkan dan mengembangkan nilai-nilai kehidupan yang dianggap penting dan perlu sehingga menjadi kepribadian atau kepemilikan peserta didik yang khas sebagaimana nilai-nilai yang dikembangkan; mengoreksi perilaku peserta didik yang tidak bersesuaian dengan nilai nilai yang dikembangkan oleh sekolah; membangun koneksi yang harmoni dengan keluarga masyarakat dalam memerankan tanggung jawab pendidikan karakter secara bersama.

Menurut Kemendiknas dalam Heri Gunawan (2012 : 259) menyatakan bahwa strategi pelaksanaan pendidikan karakter di sekolah dapat diimplementasikan dalam program pembinaan kesiswaan yang mencakup; kegiatan masa orientasi peserta didik (MOPD), masa orientasi siswa (MOS), pembinaan keimanan dan ketaqwaan kepada Tuhan Yang Maha Esa, organisasi siswa intra sekolah (OSIS), Kepramukaan, penegakan disiplin dan tata tertip sekolah, upacara bendera, pendidikan penyalahgunaan narkoba (P3N), dan pembinaan bakat minat. Hal ini juga sesuai dengan isi buku panduan Penguatan Pendidikan Karakter Bekal Generasi Emas 2045 ( 2017 : 16 ) yang menyatakan antara lain bahwa program Penguatan Pendidikan Karakter mendorong sekolah untuk menumbuhkan dan memperkuat karakter siswa melalui kegiatan ektrakurikuler, intrakurikuler, dan kokurikuler.

\section{Organisasi Siswa Intra Sekolah (OSIS)}

Menurut Setiawan. O (2018 :36) Organisasi Siswa Intra Sekolah adalah suatu organisasi yang berada di tingkat sekolah di Indonesia yang dimulai dari sekolah menengah, yaitu sekolah menengah pertama (SMP) dan sekolah menengah atas (SMA). Organisasi Siswa Intra Sekolah (OSIS) adalah satu-satunya organisasi yang ada di sekolah yang merupakan salah satu upaya dalam pembinaan kesiswaan. 
Mamat Supriatna (2010: 1), menyatakan bahwa OSIS sebagai bagian dari kegiatan ekstrakurikuler memiliki fungsi sebagai berikut:

1. Pengembangan yaitu fungsi kegiatan ektrakurikuler untuk mengembangkan kemampuan dan kreativitas peserta didik sesuai dengan potensi, bakat dan minat mereka.

2. Sosial yaitu fungsi kegiatan ekstrakurikuler untuk mengembangkan kemampuan dan rasa tanggung jawab sosial peserta didik.

3. Rekreatif yaitu fungsi kegiatan ekstrakurikuler untuk mengembangkan suasana rileks, menggembirakan dan menyenangkan bagi peserta didik yang menunjang proses perkembangan.

4. Persiapan karir yaitu fungsi kegiatan ekstrakurikuler untuk mengembangkan kesiapan karir peserta didik.

Selanjutnya Mamat Supriatna (2010 : 18) menyatakan bahwa OSIS memiliki peranan sebagai berikut:

1. Sebagai wadah, OSIS menjadi wadah dalam melatih kepemimpinan siswa melalui ektrakurikuler.

2. Sebagai penggerak dan motivator, OSIS menjadi perangsang lahirnya keinginan, partisipasi untuk berbuat, pendorong kegiatan bersama untuk mencapai tujuan.

3. Bersifat preventif, OSIS bersifat intelek dalam arti internal dapat menggerakkan sumber daya yang ada dan eksternal mampu beradaptasi dengan lingkungan dan menyelesaikan persoalan perilaku menyimpang siswa.

Penelitian yang dilakukan oleh Dyah Nursanti (2013), tentang Peranan Organisasi

Siswa Intra Sekolah dalam Membentuk Karater Siswa SMP Negeri Di Kabupaten Magelang. Hasil penelitian ini menunjukkan bahwa kegiatan OSIS dapat membentuk karakter siswa SMP Negeri di Kabupaten Magelang antara lain percaya diri, kreatif dan inovatif, mandiri, bertanggung jawab, menepati janji, berinisiatif, disiplin, visioner, pengabdian/dedikatif, bersemangat dan demokratis. Walaupun masih ada hambatan yaitu: (1) munculnya pelanggaran yang dilakukan oleh pengurus OSIS sendiri dan (2) sebagian pengurus OSIS mengeluh karena sering tertinggal pelajaran di kelas. Upaya untuk mengatasi hambatan tersebut adalah (1) memberikan sanksi secara tegas kepada pengurus OSIS yang melanggar peraturan dan (2) pengurus OSIS diharapkan dapat membagi waktu antara kegiatan di kelas dengan kegiatan organisasi.

Persamaan penelitian ini dan penelitian Dyah Nursanti adalah sama-sama meneliti tentang peranan OSIS dalam membentuk karakter siswa. Adapun perbedaannya adalah penelitian ini dilakukan di Sekolah Menengah Kejuruan ( SMK), sedangkan penelitian Dyah dilakukan di Sekolah Menengah Pertama (SMP).

\section{METODE PENELITIAN}

\section{Jenis Penelitian}

Jenis penelitian yang digunakan dalam penelitian ini adalah penelitian deskriptif. Penelitian deskriptif merupakan penelitian yang dilakukan untuk mengetahui nilai variabel mandiri, baik satu variabel atau lebih (independen) tanpa membuat 
perbandingan, atau menghubungkan dengan variabel yang lain ( Sugiyono, 2012 : 13 ). Dalam penelitian ini akan dideskripsikan peranan dari OSIS dalam pembentukan karakter siswa di SMK Negeri 2 Salatiga, dilihat dari kegiatan-kegiatan/program-program yang dilaksanakan OSIS dan keberhasilan dalam membentuk karakter siswa. Subyek atau sumber data penelitian adalah pengurus OSIS (ketua dan anggota pengurus), pembina OSIS dan sampel siswa-siswi yang menjadi anggota OSIS di SMK Negeri 2 Salatiga. Teknik pengumpulan data mengunakan wawancara, observasi dan dokumentasi. Teknik analisis data mengacu pada Miles dan Huberman (1992:15-19) yang meliputi: pengumpulan data, reduksi data, penyajian data, dan penarikan kesimpulan.

\section{HASIL PENELITIAN DAN PEMBAHASAN}

Penelitian ini mendeskripsikan peranan organisasi siswa intra sekolah (OSIS) dalam membentuk karakter siswa di SMK N 2 Salatiga tahun 2017/2018 dilihat dari, (1) kegiatan/program kerja OSIS yang disusun dan dilaksanakan; (2) karakter siswa yang dibentuk melalui kegiatan-kegiatan OSIS; (3) keberhasilan pelaksanaan kegiatan OSIS dalam membentuk karakter siswa.

Hasil penelitian menunjukkan bahwa program kerja/kegiatan yang disusun dan dilaksanakan Organisasi Siswa Intra Sekolah ( OSIS ) SMK N 2 Salatiga tahun 2017/2018 meliputi 4 program kegiatan terstruktur yaitu Classmeting, Musyawarah Perwakilan, Masa Perkenalan Lingkungan Sekolah, dan Latihan Dasar Kepemimpinan.

Kegiatan Classmeting dilaksanakan oleh OSIS pada bulan Desember. Kegiatan berlangsung selama 3 hari meliputi 2 kegiatan inti yaitu olahraga dan kesenian. Dalam pelaksanaan kegiatan olahraga terdapat 4 bidang yang di lombakan yaitu bola voli, sepak bola, basket, dan tarik tambang. Dan dalam pelaksanaan kegiatan kesenian terdapat 2 bidang yang di lombakan yaitu melukis dan bernyanyi solo. Setiap kelas diwajibkan untuk menyiapkan perwakilannya untuk mengikuti lomba. Dengan adanya perlombaan antara kelas yang terkait dengan 2 kegiatan inti tersebut mempunyai tujuan untuk menjadikan siswa lebih akrab dan saling peduli antara satu dan yang lainnya.

Kegiatan musyawarah perwakilan (MP) merupakan kegiatan yang dilaksanakan pada bulan Februari dan berlangsung selama satu hari. Kegiatan musyawarah perwakilan dilaksanakan pada bulan Februari guna mengevaluasi kegiatan - kegitan yang ada di SMK N 2 Salatiga. Kegiatan ini di ikuti oleh kepala sekolah, wakil kepala sekolah, dan pengurus OSIS, serta seluruh perwakilan dari setiap kelas yang ada di SMK N 2 Salatiga. Musyawarah Perwakilan dilaksanakan dalam 5 kegiatan inti yaitu materi Visi dan Misi (wakil kepala sekolah ), Program Kerja OSIS (ketua OSIS), Pemaparan Perencanaan Kegiatan dari Perwakilan siswa dari masing - masing kelas, tanya jawab, dan pemaparan hasil rapat. Kegiatan ini dilakukan dengan tujuan untuk menampung seluruh ide, saran serta keluh kesah siswa-siswi terhadap seluruh kegiatan ekstrakurikuler yang ada di SMK N 2 Salatiga. Kegiatan musyawarah perwakilan juga bertujuan untuk menumbuhkan rasa kepedulian, sikap demokrasi dan kritis, serta menghargai pendapat orang lain. 
Kegiatan masa perkenalan lingkungan sekolah (MPLS) merupakan suatu program dari OSIS dan sekolah yang selalu dilaksanakan pada bulan Juli yaitu awal semester satu. Kegiatan ini dilaksanakan pada awal semester satu guna memperkenalkan SMK N 2 Salatiga kepada siswa dan siswi baru. Pelaksanaan kegiatan ini berlangsung selama 5 hari yaitu hari pertama upacara pembukaan, pembekalan lingkungan sekolah, perkenalan lingkungan sekolah, gedung sekolah, guru, dan karyawan SMK N 2 Salatiga. Hari kedua Apel pagi, materi Visi dan Misi SMK N 2 Salatiga dan Tata Tertip, materi Karakter Building, apel siang. Hari ketiga apel pagi, materi kewirausahaan, materi etos kerja, apel siang. Hari keempat apel pagi, materi kebangsaan, materi kenakalan remaja, apel siang. Hari kelima upacara penutupan, penerimaan resmi siswa baru secara simbolis, pentas seni. Didalam pelaksanaan kegiatan siswa dan siswi baru diwajibkan untuk hadir tepat pada pukul 06.00. MPLS bertujuan untuk mengenalkan lingkungan dan budaya SMK N 2 kepada seluruh siswa dan siswi baru. MPLS juga mempunyai tujuan lain yaitu ingin merubah karakter dari siswa dan siswi sejak dini, yaitu menjadikan siswa lebih disiplin dan bertanggung jawab.

Kegiatan latihan dasar kepemimpinan (LDK) merupakan kegiatan yang dilaksanakan pada bulan November. LDK dilakukan karena dari pihak OSIS dan sekolah ingin melatih sikap kepemimpinan dari siswa dan siswi SMK N 2 Salatiga. Pelaksanaan Latihan Dasar Kepemimpinan berlangsung selama 3 hari yaitu hari pertama pembukaan, materi sejarah OSIS, materi perencanaan dan pembuatan program kerja, apel siang. Hari kedua apel pagi, materi karakter building, materi critical thinking, apel siang. Hari ketiga apel pagi, materi kepemimpinan, out bond, penutupan. LDK bertujuan untuk mempersiapkan pemimpin-pemimpin terbaik yang dibutuhkan oleh OSIS dan seluruh Ekstrakurikuler yang ada di SMK N 2 Salatiga. Jadi LDK merupakan kegitan pelatihan para calon-calon pemimpin siswa dan siswi di SMK N 2 Salatiga yang berkarakter baik. Kegaiatan LDK juga mempunyai tujuan menjadikan siswa lebih berkarakter dan berjiwa pemimpin.

Karakter siswa yang dibentuk melalui 4 kegiatan terstruktur OSIS tersebut yaitu Clasmeting membentuk karakter kepedulian, kerjasama, bertanggung jawab, toleransi, dan solidaritas; Musyawarah Perwakilan membentuk karakter peduli, kristis, bertanggung jawab, percaya diri, mementingkan keppentingan bersama dari pada pribadi, dan bermusyawarah untuk mencapai mufakat; Masa Perkenalan Lingkungan Sekolah membentuk karakter kedisiplinan, tertip, bertanggung jawab, saling menghargai, dan berbudaya industri; Latihan Dasar Kepemimpinan membentuk karakter disiplin, percaya diri, menghargai pendapat orang lain, dan berjiwa pemimpin.

Ke 4 program/kegiatan OSIS diatas dapat dilaksanakan dengan baik oleh pengurus OSIS, Pembina OSIS, dan siswa-siswi anggota OSIS, dan berhasil merubah karakter siswa-siswi yang semula kurang disiplin menjadi disiplin, lebih tertip, lebih peduli terhadap teman, lebih kritis dan percaya diri dalam menyatakan pendapat di depan kelas maupun di depan umum, mampu bekerjasama dengan baik dan hormat kepada guru.

Kelancaran pelaksanaan kegiatan OSIS dan keberhasilannya dalam membentuk dan merubah karakter siswa SMK N 2 Salatiga tersebut tidak lepas dari dukungan dari pihak sekolah yang mendukung dan menyediakan fasilitas untuk pelaksanaan kegiatan 
OSIS misalnya menyediakan sarana prasarana yang memadahi dalam bentuk ruangan dan lapangan tempat kegiatan, juga dari pengurus dan pembina OSIS yang disiplin dan bertanggung jawab dalam melaksanakan setiap kegiatan misalnya menyusun program/kegiatan dan melaksanakan pada waktunya, serta siswa-siswi angota OSIS yang sangat antusias dalam mengikuti kegiatan misalnya dengan hadir tepat waktu dan pulang pada waktunya.

Berdasarkan hasil penelitian ini menunjukkan bahwa OSIS mempunyai peranan yang penting dalam membentuk karakter siswa melalui program/kegiatan yang dilaksanakan, dan mempunyai fungsi preventif dalam menyelesaikan persoalan perilaku menyimpang siswa. Hal ini sesuai dengan pendapat Gunawan Heri (2012 : 263) bahwa Organisasi Siswa Intra Sekolah (OSIS) berfungsi sebagai wadah kegiatan siswa di sekolah sebagai upaya preventif dalam menyelesaikan masalah perilaku menyimpang dari siswa, dan Mamat Supriatna (2010 : 18) yang menyatakan bahwa salah satu peranan OSIS bersifat preventif, yaitu agar siswa mampu beradaptasi dengan lingkungan dan dapat mencegah perilaku menyimpang siswa. Oleh karena itu sekolah mewajibkan seluruh siswa untuk mengikuti kegiatan OSIS karena bermanfaat bagi pembentukan karakter dan perkembangan diri siswa.

\section{SIMPULAN DAN SARAN}

Organisasi Siswa Intra Sekolah (OSIS) SMK N 2 Salatiga tahun 2017-2018 mempunyai peranan yang penting dalam membentuk karakter yang baik dari siswa melalui kegiatan yang dilaksanakan yaitu Classmeting, Musyawarah Perwakilan, Masa Perkenalan Lingkungan Sekolah dan Latihan Dasar Kepemimpinan. Keempat kegiatan OSIS tersebut juga dapat merubah karakter siswa yang semula kurang disiplin menjadi disiplin, lebih tertip, bertanggung jawab mengerjakan tugas, lebih peduli terhadap teman, lebih kritis dan percaya diri dalam menyatakan pendapat di depan kelas maupun didepan umum, mampu bekerjasama dengan baik dan hormat kepada guru. Oleh karena itu kegiatan ekstrakurikuler OSIS wajib diikuti oleh siswa SMK N 2 Salatiga.

\section{DAFTAR PUSTAKA}

Gunawan Heri. 2012. Pendidikan Karakter, Konsep dan Implementasi. Bandung: Afabeta

Kemendikbud. 2017. Penguatan Pendidikan Karakter Bekal Generasi Emas 2045. Jakarta : Biro Komunikasi dan Layanan Masyarakat Kemendikbud.

Kusuma, Dharma. 2011. Pendidikan Karakter, Kajian Teori, dan Praktek di Sekolah. Bandung: PT Remaja Rosdakarya

Mamat Supriatna. 2010. Pendidikan Karakter Melalui Ekstrakurikuler. Bandung: Universitas Pendidikan Indonesia

Mucklas Samani dan Hariyanto. 2011. Pendidikan Karakter. Bandung: PT Remaja Rosdakarya 
Miles, Mathew B. Michael Huberman. 1992. Qualitative Data Analysis: A Sourcebook of New Methods. London: Sage Publication, Inc.

Nursanti, D. 2013. Peranan Organisasi Siswa Intra Sekolah dalam Membentuk Karakter Siswa SMP Negeri Di Kabupaten Magelang. Skripsi Fakultas Ilmu Sosial, Universitas Negeri Yogyakarta. Yogyakarta

Nursisto. 2002. Peningkatan Prestasi Sekolah Menengah Acuan Siswa, Pendidikan dan Orang Tua. Jakarta: Insan Cendikia

Setiawan, O. 2018. Pengaruh Aktivitas Siswa Dalam Organisasi Siswa Intra Sekolah (OSIS) Terhadap Prestasi Belajar Pada Mata Pelajaran PKN Di SMA Utama 2 Bandar Lampung. Skripsi Fakultas Keguruan dan Ilmu Pendidikan, Universitas lampung. Bandar lampung

Sugiyono. 2012. Metode Penelitian Kualitatif Kuantitatif. Bandung:Alfabeta

Suyatri, Darmiati, dan Bintoro. 2013. Implementasi Pendidikan Karakter di Sekolah. Yogyakarta: Gava Media

Zubaedi. 2012. Desain Pendidikan Karakter. Jakarta: Kencana Prenada Media Grup. 